DOT-TST-76T-29

\title{
URBAN TRANSPORTATION AND LAND USE
}

MASTER

\author{
JULY 1976 \\ EXECUTIVE SUMMARY \\ UNDER CONTRACT DOT-0S-50111-F
}

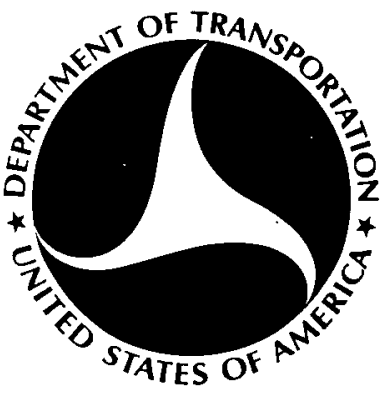

Document is available to the U.S. Public through the National Technical Information Service Springfield, Virginia 22161

PREPARED FOR:

\section{DEPARTMENT OF TRANSPORTATION}

This document is PUBLICLY RELEASABLE Bany Steele Authorizing Official Date: $2-2,67$

\section{Office of University Research}

Washington, D.C. 20590

DISTRIBUTION OF THIS DOCUMENT IS UNLIMITED 


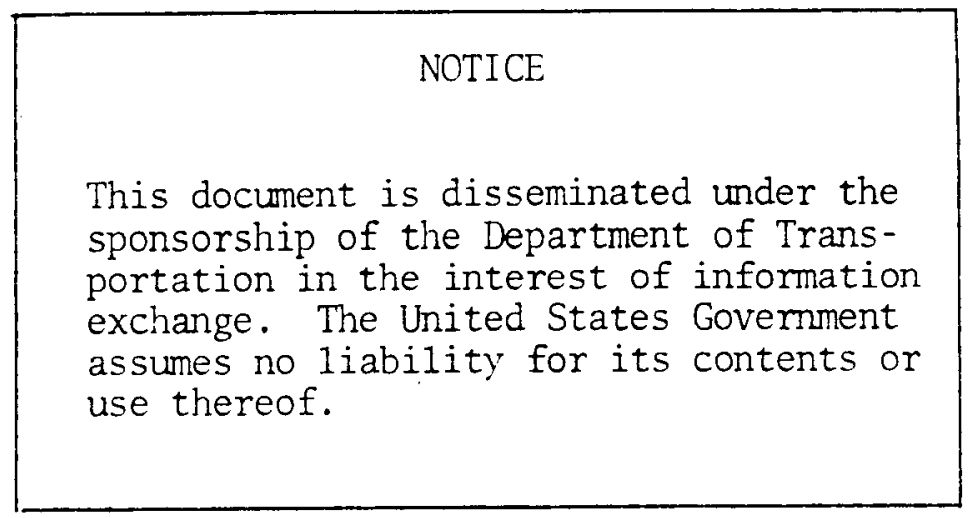




\section{DISCLAIMER}

This report was prepared as an account of work sponsored by an agency of the United States Government. Neither the United States Government nor any agency Thereof, nor any of their employees, makes any warranty, express or implied, or assumes any legal liability or responsibility for the accuracy, completeness, or usefulness of any information, apparatus, product, or process disclosed, or represents that its use would not infringe privately owned rights. Reference herein to any specific commercial product, process, or service by trade name, trademark, manufacturer, or otherwise does not necessarily constitute or imply its endorsement, recommendation, or favoring by the United States Government or any agency thereof. The views and opinions of authors expressed herein do not necessarily state or reflect those of the United States Government or any agency thereof. 


\section{DISCLAIMER}

Portions of this document may be illegible in electronic image products. Images are produced from the best available original document. 
Teclinical Repart Documentation Page

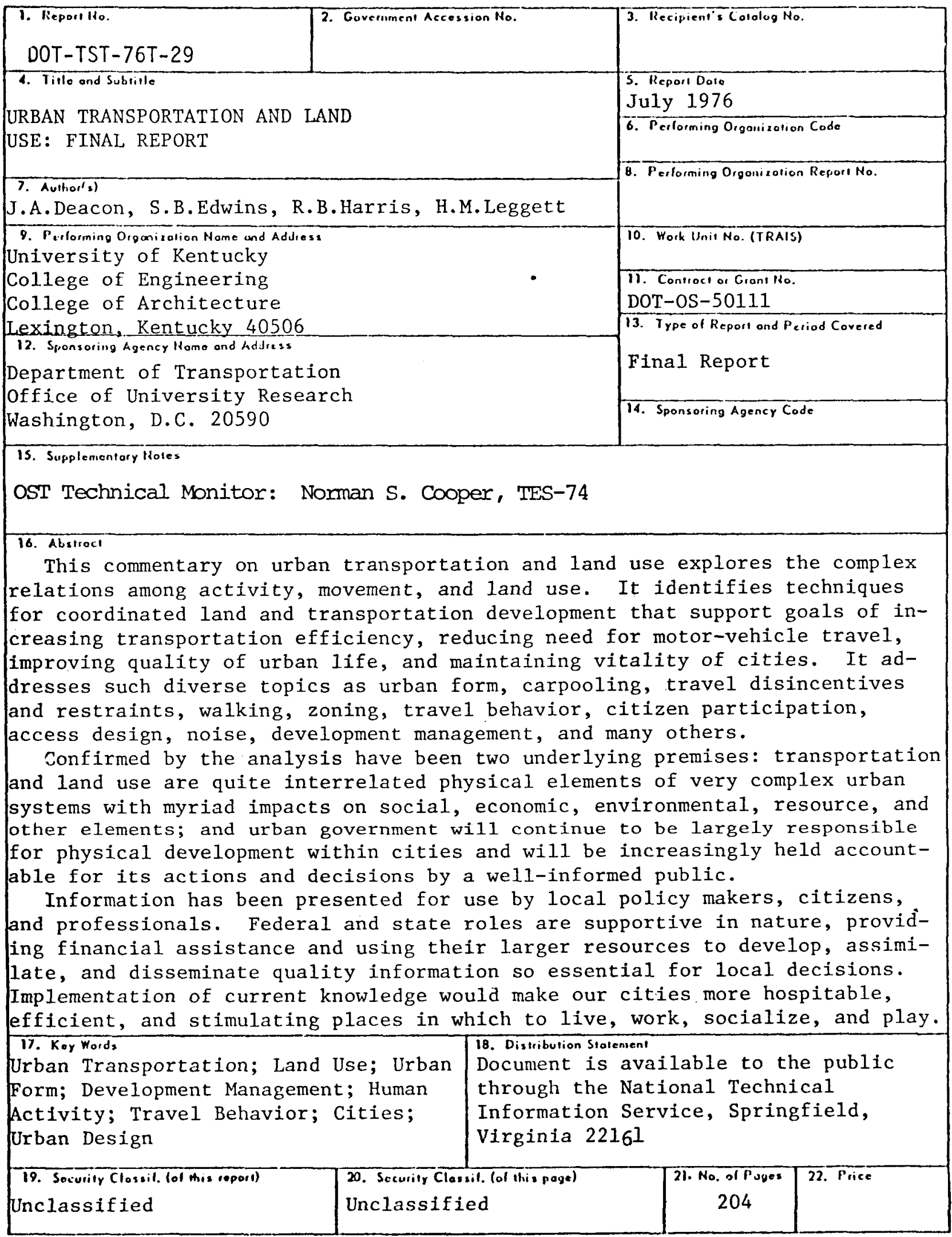

Form DOT F $1700.7 \quad(8-72)$ 
As the location of principal employment opportunities has shifted during the last decades from rural to urban areas, the character and form of urban living have changed radically. Today, most of the population live in urban settings performing highly specialized tasks and depending quite significantly on movement to utilize the many employment, social, cultural, educational, and commercial resources available. Extensive urbanization has no doubt significantly increased the variety and extent of opportunities available in cities and has contributed greatly to economic growth. However, public attention is focused on accompanying problems of difficult and costly movement which not only require excessive expenditures of time and energy but also contribute to environmental degradation.

Difficulties of travel within urban areas have been understood and treated largely as isolated transportation problems. Despite significant improvements in many components of the transportation system, urban areas have failed to achieve increasing expectations for ease of movement and improved quality of life. The almost singular focus on transportation solutions to trave1 problems obscures important relationships within the urban system and reduces opportunities to significantly improve the quality of the urban environment. Transportation and land development decisions have all too often been regarded as distinctly separate matters in analysis, planning, governmental organization, and program evaluation. Significant improvements can be expected only from a broadened focus on the combined impacts of transportation and land use decisions which strives to balance the travel generation characteristics of land-based activities with the movement capabilities of the transportation system.

Th1s commentary on urban transportation and land use explores the complex relationships among activity patterns of urban inhabitants, movement systems, and patterns of land development and urban form. It recognizes transportation and land use to be two, quite interrelated physical elements of very complex urban systems with myriad, related impacts on social, economic, environmentàl, resource, and other urban elements as well. It Identifies techniques for, and processes of, coordinated land and transportation development supportive of the overall goals of increasing transportation efficiency, reducing the need for private motor vehicle travel, improving the quality of urban life, and maintaining the vitality of cities. It addresses a host of such diverse topics as urban form, urban design, carpooling, travel disincentives, pedestrian movement, zoning, traffic restraints, preferential treatment of buses, travel behavior, citizen participation, access design, transportation noise, development management processes; and many others.

Urban government has always been, and will most likely continue to be, largely responsible for managing physical development within cities and will Increasingly be held accountable for its actions and decistons by a well-informed public. For this reason, the information and guidelines reported herein have been assembled for use at the 
local level by public policy makers, interested citizens, and professionals in the planning and design disciplines. Federal and state roles in the urban setting are seen to be supportive in nature, providing financial assistance and bringing their larger resources to bear upon the development, assimilation, and dissemination of high-quality Information so essential for rational decision making by urban governments. Areas of potentially useful research and development activities have been identified primarily for use by these higherlevel governmental entities.

As reported herein, the basis for understanding physical development of urban areas begins with a collection of information about the nature of urban places, developments in urban transportation, and characteristics of urban activity and travel behavior. The relationships between transportation and land development are viewed in three different contexts: (1) physical relationships at the macroscale which are of long-term significance and generally considered as a part of the planning process, (2) physical relationships at the microscale which are of both short- and long-term significance and generally considered as urban design issues often at the scale of particular sites or facilities, and (3) process relationships which deal with the legal, administrative, financial, and institutional aspects of coordinating $l$ and and transportation development.

A number of factors contribute to the difficulty of solving transportation problems: they are often considered, examined, improved, and evaluated somewhat independently of remaining elements of the complex urban system; there are no commonlyaccepted, system-wide performance measures; divisions of responsibility between levels of government are unclear; and the array of governmental jurisdictions and authorities inhibit system-wide planning, design, implementation, and operation. Competition for revenues for shorttern improvement projects and the nature of the political process curtail long-term capital improvements and continuity of effort. Most importantly, activity patterns and the physical arrangement of activity places lead to excessive travel peaking, long trip lengths, and a diffusion of origins and destinations. Finally, urban government has not effectively considered the impacts of transportation and development changes on the urban environment.

The authors believe that one of the most pressing needs is a suitable means for measurement of urban system performance that is system-wide and based on accepted standards for data collection and that incorporates criteria for performance comparisons and evaluations. Data on the specific impacts of improvements, such as changes in development and travel patterns, and on their effects on system efficiency would aid future decisions.

Improvements to urban transportation have often emphasized long-term, capital-intensive, and hightechnology solutions. No doubt a number of these, such as personalized rapid transit or dual-mode systems, hold promise for specific urban applications: high-speed intercity travel w111 doubtlessly be alded by advanced systems. But significant improvements can also result from the application of low-cost operational techniques to existing systems. Seldom have short-term, low-cost improvements been properly integrated in the planning and design process with long-term, high-cost improvements. New emphasis on system-wide transportation plans, required under UMTA and FHWA joint regulations, will promote proper attention to low-cost alternatives. Significant benefits can be anticipated only through the simultaneous application of many varied techniques applied through comprehensive local effort.

Operational improvements for efficient use of existing systems include, among others, the following: improved traffic operations to control the flow of vehicles; preferential treatment for transit and other high-occupancy vehicles; improved provisions for pedestrians and bicycles; management and control of parking; changes in work schedules; minor reconstruction; and access controls on major roadways.

Actions are recommended herein for reducing vehicle use in congested areas and on congested facilities and for increasing transit service to centralcity residents. Bus service is the backbone of public transportation and finds extensive utility especially for work trips. Taxi service is often the only public transportation service available in smaller communities. Improvements in these services depend on improved vehicle design and on refinements in scheduling and routing, which. increase operational efficiency as well as convenience (shorter walking distances to stops, less waiting time, and ease of transfer). More frequent scheduling of bus service and the provision of jitney service along specific routes can also improve mobility for transit users. Light rail service on existing rights-of-way provides an effective commuter service along moderate density corridors.

Our study of relationships between transportation. and urban form indicates the lack of common1y accepted nomenclature on which to base analysis and theory: consequently, information from one urban area often cannot readily be transferred to another. However, there is absolutely no doubt that transportation has historically exerted a major influence on urban form. In response to the vast population migration to cities, transportation sys..m improvements expanded the land area availabj. Cor development and created a dispersed pattern : urban activities. The inexpensive and highly accessible peripheral locations now attract urban migrants and encourage decentralization of activities, further altering the traditional form of cities. Urban travel is longer, more complex, and largely automobile-dependent in the lowdensity dispersed form. Scatteration unfortunately reduces the efficiency of public transportation except along those routes bordered by concentrated development.

Measures for guiding the development of land in ways which reduce urban travel and increase efficiency of the transportation system can be based on identified hierarchal structures for transportation and activity locations. Signifi- 
santly more information on locational dectsion processes will be necessary to determine the complicated interaction of decisions which affect urban form in order to develop intervention policles. However, effective techniques are available which substitute proximity for travel by suitable organization of land uses. Areas which are uni-functional and separated can become integrated with new multi-functional activities. Multi-use centers, located near residences for household-related activities, reduce travel distance and complexity and encourage walking and bicycling. Travel reduction by mixed use, land use clustering and minimization of separated single-purpose zones is complemented by developing multi-functional activity centers.

Thus, shopping and commercial centers which combine a number of activities, such as entertainment, recreation, and personal business, reduce the number of trips to separate locations. Apartments and elderly housing designed in concert with such centers increase pedestrian accessibility. Trave1 reduction by proximity requires careful attention to the design of both residential areas and activity centers and suggests that zoning must permit a wider variety of mixed uses than has heretofore been permitted.

A classification system for highways and streets, based on the functional characteristics of each component, is urgently needed to guide processes dealing with street geometrics and design, access location and design, and the determination of appropriate abutting land uses and individual site layouts. Current Federal classification practices are inadequate for such purposes.

Highway performance is affected by the control, location, and design of access points: it is often aggravated on major roadways by the frequently conflicting rights of the traveling public and the abutter's rights of access. Serious degradation of street and highway service may result from ineffectively treating access conflicts. It is increasingly recognized that the compromises inherent in multipurpose streets which attempt to simultaneously serve movement, access, and storage functions are frequently counterproductive and unacceptable. An increasingly specialized, hierarchal system of streets is necessary for properly integrating transportation with activity spaces.

Adverse environmental effects of transportation, such as noise, vibration, air pollution, and visual intrusion, are very serious problems in many urban situations. Noise, vibration, and pollution problems can be greatly reduced by government and industry action in facility and vehicle design. Incompatible land uses should not abut those transportation facilities which generate excessive noise and air pollution. Buffer location and design are important elements In ameliorating direct environmental consequences of major transportation routes as are selective vehicle-use and temporal restrictions.

Joint development and multiple use of transportation rights-of-way integrate diverse physical elements
Ind Influence land development patterns. Incorporation of utilities, buffers, park space, alternative modes, and other land uses in transportation rights-of-way can improve transportation performance, reduce costs, and create social, economic, and aesthetic harmony. These techniques for directing and staging urban development demand more clearly deflned legislative and agency support.

Improvements in the walking environment require a comprehensive approach by urban governments, supported by increased public expenditures, in order to develop a variety of both small- and large-scale improvements which are coordinated with more closely arranged proximity between activities. Walkways between and within activity centers are a high-priority planning and design consideration to remove conflicts within activity centers and across major movement routes.

Parking is a neglected component of the urban transportation system. Because of its significance as an interface between mode changes and the locus of numerous vehicle/pedestrian conflicts and hazards, it is recommended that local areas develop comprehensive parking policies in coordination with other techniques for improving movement efficiency, reducing automobile usage, and encouraging pedestrian movement. Activity levels can be altered by the availability, convenience, and cost of parking, affecting in turn land development and the activity system. As an enormous land user and important element within the movement system, parking can be structured with policies designed to achieve broad urban objectives and to guide urban development.

Motor trucks, the prime movers of urban goods, constitute a major element of the urban transportation system, and their proper accommodation is essential for efficient operation of the city. While goods movement has been a primary responsibility of the private sector, significant improvements are unlikely without increased governmental involvement. Solutions to on-street parking problems and increased trucking efficiency are possible by means of improved design and location of terminals and incentives to consolidate freight and reduce travel duplication.

Railroad facilities which conflict with highway flow and present a safety hazard can of ten be Improved through coordinated and joint development efforts. The railroad influence on urban land use patterns is often underestimated. Right-ofway abandonment and railway relocations present a unique opportunity for local government to influence land development. Potential abandonments should be identified at an early stage for possible conversion to open space, recreation, and bikeway use; for adaptive re-use; for development as light rall facilities; or for other present or future uses.

Our revlew of land development processes and the rapld growth of legislation documents a considerable, and perhaps intolerable, level of institutional obsolescence, and an urgent need for urban government to develop more effective means with 
which to formulate policy and utilize extsting development tools.

Processes must be adopted through which urban government can define common goals, identify long-term consequences of land use decistons and transportation improvements, and incorporate citizen partictpation in each level or stage of decision. National guidelines for environmental quality, regional review processes now required by law, and guidelines for transportation and community development planning, all emphasize coordination of programs at the local level. In most localities, an armada of development tools is available and the legality of local growth control and management methods has been more clearly established by the courts. Local governmental initiative must be supported by comprehenstve guidelines for a planning, management, and evaluation process to actively direct development through considered transportation and land use decisions. Piecemeal, project and program planning is no longer acceptable.

Findings reported herein have immediate utility to those involved in the planning, management, and operation of cities: administrators, planning staffs, program designers, commissioners, aldermen, citizen groups, advisory boards, etc. The extensive recommendations for research and development, also reported herein, may be useful to state and Federal agencies whose responsibilities encompass improving the physical environment, solving transportation problems, reducing energy consumption, and providing citizen access to needed opportunities. Of particular importance is a recommendation that the Federal government design and implement a comprehensive, continuing Urban Development Information System, a 11brary of useful information and guidelines devoted to all elements of urban policy, planning, participation, design, and implementation.

Improvements in the urban environment increasingly require the attention of urban government to the combined impacts of land use and transportation decisions. Consideration of activity locations, zoning revisions, and low-cost improvements in existing systems can effectively improve transportation performance. Greatly increased local initiative in guiding the location of urban services and activities may be more effective than further refinements in regulation and control as a means for improving transportation efficiency, for reducing vehicular travel, and for improving the quality of urban life. 


\section{IF YOU WISH TO RECEIVE A \\ COMPLIMENTARY COPY OF THE REPORT PLEASE FILL OUT THE FOLLOWING: DOT-TST-76T-29 \\ TITLE OF THE REPORT:}

\section{AUTHOR:}

AUTHOR'S UNIVERSITY:

NOTE: Compiimentary copies will only be supplied as long as existing stocks last.

FOLD

DEPARTMENT OF TRANSPORTATION

OFFICE OF THE SECRETARY

WASHINGTON D.C. 20590

Official Business

FOR PRIVATE USE, $\$ 300$
POSTAGE AND FEES PAID

DOT 518

FIRST CLASS
FOLD

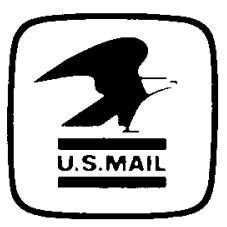

REPORTS ADMINISTRATOR, TST-60 OFFICE OF UNIVERSITY RESEARCH U.S. DEPARTMENT OF TRANSPORTATION 400 SEVENTH STREET, S.W. WASHINGTON, D.C. 20590 
DEPARTIENT OF TRANSPORTATION

OFFICE OF THE SECRETARY

Washington, D.C. 20590

nfficial Business

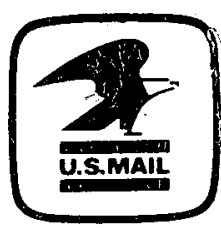

PENALTY FOR PRIVATE USE, $\$ 300$

Drs-5] -514

ATOMTC MMTREY COM

DIV OF TECH IIMO EXTTN

PO BOX 62

OLK RIDGI TN 37830

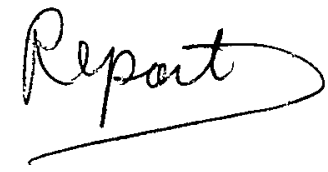

\section{IF YOUR ADDRESS ABOVE IS INCORRECT OR IF THIS IS A BORROWED COPY PLEASE FILL OUT THE FOLLOWING:}

NAME

USE BLOCK LETTERS

\section{ADDRESS}

